\section{B A Institute of \\ YK Business Administration \\ 六下 \\ Karachi \\ Leadership and Ideas for Tomorrow}

Business Review

Volume 8 Issue 1 January-June 2013

$1-1-2013$

\title{
Lead-lag relationship in spot and future market: Evidence from Pakistani Stock Market KSE-100 Index
}

Hamid Ullah

Abdul Wali Khan University, Mardan

Attaullah Shah

Institute of Management Sciences, Peshawar

Follow this and additional works at: https://ir.iba.edu.pk/businessreview

Part of the Corporate Finance Commons

\section{(c) (1)}

This work is licensed under a Creative Commons Attribution 4.0 International License.

\section{Recommended Citation}

Ullah, H., \& Shah, A. (2013). Lead-lag relationship in spot and future market: Evidence from Pakistani Stock Market KSE-100 Index. Business Review, 8(1), 135-148. Retrieved from https://doi.org/10.54784/ 1990-6587.1221

This article is brought to you by iRepository for open access under the Creative Commons Attribution 4.0 License and is available at https://ir.iba.edu.pk/businessreview/vol8/iss1/10. For more information, please contact irepository@iba.edu.pk. 
https://ir.iba.edu.pk/businessreview/vol8/iss1/10

DOI: https://doi.org/10.54784/1990-6587.1221

Business Review - Volume 8 Number 1

January - June 2013

\title{
ARTICLE
}

\section{Lead-Lag Relationship in Spot and Future Market: Evidence from Pakistani Stock Market KSE-100 index}

\author{
Hamid Ullah \\ Abdul Wali Khan University, Mardan \\ Attaullah Shah \\ Institute of Management Sciences, Peshawar
}

\begin{abstract}
This paper has investigated the Efficient Market Hypothesis (EMH) through the concept of lead-lag relationship of the future market prices and spot market prices in the context of Pakistani stock market. The study has used data of randomly selected one hundred and forty firms listed on the Karachi stock exchange from January 1995 to March 2012. Spot and future indexes have been developed from the closing prices through the Price-Weighted index method. First stationarity of the data has been checked through AugmentedDicky Fuller test then GARCH $(1,1)$ model has estimated for both the spot and future index returns in order to investigates the volatility in either of the index. The results of GARCH $(1,1)$ suggested that the impact of the previous day volatility in both the spot and future index has impact on the current day volatility. The future market price volatility has more prominent value to explain the spot market prices as compared to that of the explanatory power of the future market prices based on the spot market prices. Therefore it has concluded based on the GARCH $(1,1)$ there exists lead-lag relationship between the future and spot index and future market leads the spot market. Granger casualty test has used to triangulate the results of GARCH $(1,1)$ model. The results showed that future market Granger causes the spot market while the spot market does not Granger causes the future market. Thus it can be concluded that it is the future market prices that lead the spot market prices and thus there exist a Lead-Lag relationship between the future and spot market prices in Karachi stock exchange and one can predict changes spot market price based on the changes in the future market price. Moreover, these empirical results support the view that it's the future market where information has created about the security prices and then it disseminate to the spot market. This study shall help the investors in the establishment of the investments strategies for Pakistani stock markets.
\end{abstract}

JEL Classification code: C22, G10, G13, G15 
Key words: Spot index, Future Index, Lead-Lag relationship, Granger Casualty, GARCH, Volatility.

\section{$1.0 \quad$ Introduction}

The weak form of the efficient market hypothesis in the spot and future markets have gotten sufficient attention from the research students, academics and practitioners due to the market volatility and arbitrage opportunity available with the investors to outperform the market. The term efficiency of the market means that all information about the securities has been reflected in the prevailing market prices (Fama 1960). Therefore, any good or bad news information disseminated to the market would incorporate in the spot as well as the future prices instantaneously. But what if the news has not reflected in both the spot and future markets simultaneously. Then the question arises that which market has the capability of discovering the prices and then which market shall follow it. Thus if market is not efficient, then there can be leadlag relationship between the two markets.

The concept of the price lead- lag relationship of the future index with the underlying spot index is that how quickly one market incorporates the newly arrived information as compared to other, and how much the two markets are associated with each other. In efficient market the price movements in the two markets are not auto-correlated and there has no lead-lag relationship. However, if the reaction to news of the two market is not simultaneous than there would be a possibility of leadlag relationship between the two markets.

A good number of researches investigated the significant lead-lag relationship of the futures index and underlying spot market (Finnerty and Park (1987); Kawaller, Koch, and Koch (1987); Harris (1989); Stoll and Whaley (1990)). Their empirical findings support the inefficiency of the future and spot markets and suggested that the future market significantly leads the spot market. However, there has been weak evidence for the spot market to predict the future market.

The price discovery feature of the derivatives market has a vital role in the relationship between the future and spot markets. Booth et al.(1999), suggested that price discovery has the process through which the new information incorporated in the securities prices that would lead the share prices to attain equilibrium. Analytically, it has been verified in different studies that derivatives market enclosed good or bad news information and later on the same information reflected in the stock price. Thus there exists a lead-lag relationship between the future and the spot markets (Frino et al.2000; Thenmozhi 2002; Mukherjee and Mishra 2006; Floros and Vougas 2008; Tse and Chan 2010).

The market dynamics and institutional set up of the financial markets have differences in the microstructure and transaction cost that lead the returns of the one market while the second market follow it. Therefore, there exist plausible views about arbitrage profit. (Chan and Chung 1993; Sofianos 1993).

This paper has contributed in the sense that it is the first study that has used the future contract data while testing for the lead-lag relationship between the future and spot markets in Pakistani 
context. Secondly a good number of statistical techniques have been used for investigation that has not been used before simultaneously.

The paper has been organized in different sections such as introduction provides an overview of the concept with the contribution of the study. The second section is literature review that showed the different theoretical and empirical work up to the date. Third section composes of research designed and methodology that explain the data set and different techniques used in the study. Fourth section is based on the analysis that showed the empirical results with interpretation. The fifth section represents the conclusion and future scope of the study.

\subsection{Literature Review}

Literature on the derivative and spot market has mainly been divided in to three main broad sections. Firstly the derivative markets' impact on the spot market and behavior of the derivative exchange markets. Secondly the behavioral aspects of the spot market position near to the expiration dates of the future contracts. Thirdly investigation of leader and follower relationship between the spot and derivative market across the emerged economies but very little is known about the emerging markets due to non-availability of derivative market data.

Zeckhauser and Niederhoffer (1983) conducted the first survey on the relationship between the spot and the future markets. The survey concluded that future market prices have the capability of forecasting the changes in the spot market prices in short terms.

Kawaller, Koch and Koch (1987) investigated a bidirectional intra-day price lead-lag relationship between the spot and the future market while using trading data of S\&P 500 future with one minute gap. Their empirical results suggested that there exists a significant lead-lag relationship between the future and spot market. Furthermore they showed that future market lead the spot market by twenty to forty five minutes. While the spot market leads the future by just two minutes.

Herbst et al. (1987) investigated the stock and future market relationship through cross correlation for the period of February 1982 and September 1982. Their findings suggested that the future market leads the spot market from zero to sixteen minutes. Kawaller, Stoll and Whaley (1990) tested empirically causal relationship between the future and spot market while using intra-day data of S\&P 500 with that of the Major Market Index. The empirical results supported a causal relationship between the spot and future markets. Moreover, future markets lead more stronger than the spot market.

Stoll and Whaley (1990) suggested that there exists a lead lag relationship in five minutes intervals prices of S\&P 500 futures market with that of the spot market. They showed that future market strongly lead spot market while week lead-lag relationship evidenced in reverse direction. (Pizzi et al. 1998).

Chan (1992) suggested the existence of the leader and follower relationship between the future market returns and spot market returns while using the inter-day stock returns of the S\&P500 and Major Market Index (MMI). The author has investigated lead-lag relationship of the future and spot market based on the good and bad news differential effect, trading and size of the two markets with their movements. 
Chan et al. (1991) investigated relationship between the stock returns and returns volatility of the future and stock index of S\&P500 market data for time period of 1984 to 1989. Generalized AutoRegressive Conditional Heteroskedasticity (bi-variate GARCH) has used to test for the lead lag relationship between the spot and future markets and concluded that none of the market price can be forecast with changes in the other market. Furthermore they suggested prominent bi-directional dependence relationship between the returns and also returns volatility of the both spot and future market. There has been no lead-lag relationship between the changes in the price and volatility between the future and spot market. So both the future and spot markets can act as significant discovery place in the prices and the news disseminates quickly in both of the markets.

Wahab and Lashgari (1993) provide contrary results to the above studies while using daily data of FTSE 100 and S\&P 500 index from 1988 to 1992 while investigating causal relationship between spot and future market through co-integration. They evidenced strong lead-lag effect from spot market to future while weak in strength from future to spot market.

Abhyankar (1995) conducted his study on lead-lag relationship in the London's stock and future market while using hourly data form 1986 to 1990 . The empirical results of E-GARCH model suggested a contemporaneous association between the spot and future market. Future market leads the spot market in mean. The author argued that more traders with information enter the future market as compared to the spot market due to the existence of lower cost in the entry and transaction in the future market. So any good or bad news information assimilated much faster in the future markets and thus provide an opportunity for traders to speculate. He further added that at the time of high volatility and moderate good and bad news, the spot market lead the future market.

Kutmos and Trucker (1996) investigated the relationship between the S\&P 500 index and S\&P 500 Future index while using daily closing prices for the time period of 1984 to 1993 through the bivariate E-GARCH procedure. The empirical results suggested that in short run the future market and spot market dynamics are the same. Any news impact in the future would lead to increase in the volatility of the spot market through asymmetric ways. However any innovation initiating in the stock market has no effect on the volatility of the future market.

Cheung and Fung (1997) investigated daily data of three months Eurodollar stock rate and future rate for the period of 1983 to 1997. They used co-integration, Ganger causality test and ARGARCH model for the testing of relationship between the two rates. The empirical results of these models supported the bi-directional casualty between the two markets. Silvapulle and Moosa (1999) suggested that futures market prices of the crude oil lead the stock prices. Their conclusion has been based on the daily prices from 1985 to 1996 while using the linear causality test. Moreover, they also used nonlinear causality tests which suggest that both of the market react to the good and bad news information simultaneously without time differentiation.

Booth et al. (1999) investigated the German market of future index, option index and stock index while using intraday transactions. The empirical results showed that future market and spot market are helpful in providing information about each other while the option market has weak informative relationship between the shares and option index. 
Frino et al. (2000) investigated the news impact on the future and spot market while using correlation technique of analysis. The findings suggested that economic news have impact on the spot market and then that effect has shown in the future market later on. So there exists a lead lag relationship between the spot and future markets.

Roope et al. (2002) investigated the Taiwan Index future that is listed in both the Singapore as well as Taiwan stock market. Their empirical results suggested that information effects on the prices are originated in Singapore and then it has been carried forward to the Taiwan future markets. Therefore, there exists lead-lag relationship between the two market future contracts and spot prices.

Thenmozhi (2002) and Anand-babu (2003) invested lead lag relationship between the Nifty future and spot index for the daily prices. Their findings suggested that the future market has led by one and two days the spot market. They further added that it's the future market that has good power of information disseminating and thus play a vital role in the change in prices. So therefore due to more information origination in the future market that can leads to the spot markets.

Mukherjee and Mishra (2006) suggested a contemporaneous and bidirectional relationship between the Nifty future and index and spot index in India while using a daily data for the period of six months ranging from April 2004 to September 2004.

Hoque, Kim and Pyun, (2006) investigated the mean reverting behavior of the eight financial markets based on weekly data from April 1990 to February 2004. Their findings suggested that out of those eight markets Singapore, Indonesia, Thailand, Philippines and Malaysia showed predicable behavior and mean revision exists while in Korea and Taiwan, the results failed to support the mean reversion.

Floros and Vougas (2008) investigated the Greek market efficiency while using data set of 1999 to 2001. Their findings suggested that the futures market of the Greek is more efficient than the stock market. Zhang et al. (2010) investigated the Future market efficiency by applying random walk hypothesis and unit root test. The empirical results suggested that the market prices of 51 out of 54 futures contracts fulfill the sufficient condition of the market efficiency. The future prices follow a random walk hypothesis implies that the market is efficient.

\subsection{Research Design and Methodology}

This section includes the sample framework, the data sources from where the data has been collected and used for the analysis and the models that have been used for the estimation and testing of lead lag relationship between the future and spot prices.

\subsection{Sample framework and Data sources}

This study has been conducted considering a random sample of forty such firm that are traded in Karachi Stock Exchange(KSE) in both the future and spot market for the period of January 2005 to March 2012. Daily stock and futures closing prices have been collected for those trading days where the trading of both the spot and future has been done simultaneously, accounted for 248000 
observation form the KSE official website ${ }^{2}$. Spot and future indexes have been developed from the closing prices of the one hundred forty firms through the Price-Weighted series like Dow Jones Industrial Average (DJI), Nikkei-Dow Jones Average (NDJA). Returns from both of the indexes has calculated by the below equation.

$$
R_{1}=L N\left|P_{+1}\right|
$$

\subsection{Descriptive statistics}

The descriptive statistics will show the distributional characteristics of the spot Index and future Index. It usually contains the minimum, maximum, mean, deviation, Skewness and Kurtosis. Table 3.1 shows the descriptive statistic of the study.

\subsection{Unit Root Test of Stationarity}

Unit root test has been conducted to check for the stationarity of data. If the data has stationarity and no trends exist, then that data can be used for the further estimation. The unit root test was based on the concept that stock prices have random walk patterns and there has no trends in their behavior. Therefore it can be suggested that a random walk series is that series in which today stock prices equal to the previous day stock prices plus the random shift or shock as shown in the below equation. The Unit Root test results are given in table 3.2.

$$
p_{F}=\rho P_{F(t-1)}+\mu_{t}
$$

\subsection{Modeling Volatility of Spot Index and Future Index.}

Generalized Autoregressive Conditional Heteroskedasticity (GARCH) model has used for modeling the spot index and future Index volatility and its impact on each other. Bolerslev (1986) modified the ARCH model that has presented by Engle (1982) model to the GARCH that allowed the researchers to use more lag in equation. Engle and Patton (2001) supported that GARCH has effectively modeled the volatility of the financial assets. GARCH model equation has been given below.

$$
\begin{aligned}
& R_{s i}=\gamma_{R_{F}}+\mathcal{E}_{t} \\
& \sigma_{\mathrm{t}}^{2}=\alpha_{o}+\sum_{i=1}^{p} \alpha_{i} \varepsilon_{t-i}^{2}+\sum_{i=1}^{q} \beta_{i} \sigma_{\mathrm{t}-\mathrm{I}}^{2}
\end{aligned}
$$

Where

$\sigma^{2}=$ Conditional variance of the time series.

$\varepsilon_{t-i}^{2}=$ Autoregressive Conditional Heteroskedasticity (ARCH)

${ }^{2}$ http://www.kse.com.pk/ 


\section{$\sigma_{t-i}^{2}$}

$=$ Generalized Autoregressive Conditional Heteroskedasticity $(\mathrm{GARCH})$

$A$ and $\beta \geq$ to assured that the GARCH model is stable and the Conditional variance has some positive value. In this paper GARCH $(1,1)$ has estimated based on the Schwarz Criteria and Akaike Information Criteria. In the GARCH equation the term $(1,1)$ showed the first lag has used while estimating the equation for the $\mathrm{ARCH}$ and $\mathrm{GARCH}$.

\subsection{Granger Casualty}

In order to find out the casual relationship between the spot index and future index returns, Granger casualty test has used. This test will help us to investigate the lead-lag relationship between the future and spot indexes. This test has used for the lead-lag for the reason that it is based on the concept that all information in one variable that we want to forecast has solely present in the other time series variables.

\section{Empirical Analysis}

This section consist of the empirical results of the study that includes descriptive statistics, Stationarity test, GARCH $(1,1)$ and Granger Casualty test for the lead lag relationship between the spot and spot Index has been reported.

\section{a. Descriptive statistics}

The descriptive table shows that the number of observation used for the analysis are 1695 . The minimum value of the future -0.745 while that of the spot has -0.724 , maximum value of the future index has 0.346 while spot has 0.337 , standard deviation of the future index has 0.139 and the spot index has 0.144. The ADF test results show that the both of the future and spot index are stationary. The ADF value of the spot is 39.54 and the future index has 35.57 both of these values are higher than the critical value that is -3.434 at $1 \%$ significance level.

Table 4.1 Descriptive statistics, Augmented Dicky-Fuller Test for Future and Spot Index.

\begin{tabular}{|l|l|l|}
\hline Items & Future Index & Spot Index \\
\hline No of Observation & 1695 & 1695 \\
Minimum & -0.745 & -0.724 \\
Maximum & 0.346 & 0.337 \\
Median & 0.012 & 0.019 \\
Standard Deviation & 0.139 & 0.144 \\
Skewness & -1.845 & -1.954 \\
\hline
\end{tabular}




\begin{tabular}{|l|l|l|}
\hline Kurtosis & 11.665 & 11.322 \\
Jarque-Bera Test & $299.754^{*}$ & $313.056^{*}$ \\
ADF Test & $-35.57 * * *$ & $-39.54 * * *$ \\
\hline
\end{tabular}

Table 4.1 represents the number of observation, mean minimum, maximum, standard deviation, median, skewness, Kurtosis and ADF (Augmented Dicky-Fuller test). *** shows the level of significance for the future and spot market index.

\section{b. Correlation of Future Index Returns and Spot Index Returns}

Correlation shows the linear association between the two variables. In our case the correlation between the spot and the future is about 0.936 which shows that spot and future index returns are positively correlated while the magnitude shows the intensity of the relationship is very high. Thus the spot and future index can have the capability of leading each other but the direction of the relationship as to which price leads is unknown.

Table 4.2 Correlation analysis of Future and spot Index.

\begin{tabular}{|l|l|l|}
\hline Item & Future Index & Spot Index \\
\hline Future Index & 1.000 & 0.936 \\
\hline Spot Index & 0.936 & 1.000 \\
\hline
\end{tabular}

Table 4.2 showed the correlation between the future index and spot index.

\subsection{Discussion and Estimated Results of GARCH $(1,1)$ Future Index as dependent and Spot Index Returns as independent variable.}

GARCH $(1,1)$ model has been used to estimates the volatility of the future index based on the spot index returns as shown in Table 4.3. The empirical results of the ARCH and GARCH suggested that current volatility has been directly and positively affected by the last period volatility as well as the square of the residuals of the last period. The mean equation coefficient has positive value of 0.4809 and it is statistically significant lead to the conclusion that there has a direct relationship between the future index volatility with that of the spot index volatility. The variance equation shows that both $\alpha$ and $\beta$ have coefficients of 1.4572 and 0.2277 are positive and highly statistical significant at $1 \%$ significant level. The results suggested that volatility in the future prices has been due to the ARCH term more than the GARCH term of the estimated equation. Based on the above results, we can conclude that the volatility in the future market is due to the volatility in the spot market and the sum of $\alpha+\beta>1$ which further suggested the volatility response of the spot prices on the future is going to increase over time (Chou,1988).

Table 4.3 GARCH $(1,1)$ Model: Future Index Returns as dependent variable and Spot Index 
Returns as Independent variable.

\begin{tabular}{|l|l|l|l|l|}
\hline Items & Coefficient & Std. Error & Z-Statistics & Probability \\
\hline & & Mean Equation & & \\
\hline S.I.R & 0.4809 & 0.00469 & 102.51 & $0.000^{* * *}$ \\
\hline & & Variance & & \\
& & Equation & & \\
\hline ARCH(1) & 0.0376 & 38.712 & $0.000^{* * *}$ \\
GARCH(1) & 1.4572 & 0.0080 & 28.32 & $0.000^{* * *}$ \\
\hline Schwarz Criterion & 0.2277 & -5.113 & \\
Akaike information Criterion & -5.126 & \\
Log likelihood & 430.90 & \\
\hline
\end{tabular}

Table 4.3 shows the GARCH(1,1) results where S.I.R is spot Index returns while in the parenthesis of ARCH and GARCH $(1,1)$ shows the lag terms. *** shows the significance level.

\subsection{Discussion and Estimated Results of GARCH $(1,1)$ Spot Index as dependent and Future Index Returns as independent variable.}

In order to investigat the impact of the future price volatility on the spot prices GARCH $(1,1)$ has been estimated as shown in the table 4.4. the empirical results suggested that spot market volatility can be explained by the volatility in the future market but the explanatory power of the spot market volatility to explain the future market volatility has greater than the former one. The mean equation has a coefficient of 0.3351 and has statistically significant at $1 \%$ level of significance. So there has a direct positive influence of the future market volatility on the stock market volatility. The spot market volatility can be forecasted based on the volatility in the future market prices. The variance equation showed that ARCH (1) and GARCH (1) has coefficients of 0.0568 and 0.8672 and has statistically significant at the $1 \%$ level of significance. The sum of $\alpha$ and $\beta$ is less than one $(\alpha+\beta<1)$ which further suggested that volatility shocks in the spot prices decay at lower rate. The impact of the volatility in the spot market prices due to the future market prices will decrease over time.

Table 4.4 GARCH $(1,1)$ Model: Spot Index Returns as dependent variable and Future Index Returns as Independent variable.

\begin{tabular}{|l|l|l|l|l|}
\hline Items & Coefficient & Std. Error & Z-Statistics & Probability \\
\hline & & Mean Equation & & \\
\hline F.I.R & 0.3351 & 0.0052 & 64.49 & $0.000^{* * *}$ \\
\hline & & Variance Equation & & \\
\hline ARCH(1) & 0.0568 & 0.00558 & 10.18 & $0.000^{* * *}$ \\
GARCH(1) & 0.8672 & 0.00695 & 124.61 & $0.000^{* * *}$ \\
\hline Schwarz Criterion & & -5.204 & \\
Akaike information Criterion & -5.217 & \\
Log likelihood & 442.06 & \\
\hline
\end{tabular}

Table 4.3 shows the GARCH $(1,1)$ results where F.I.R is Future Index returns while in the parenthesis of ARCH and GARCH $(1,1)$ shows the lag terms. *** shows the significance level. 


\subsection{Engle Granger Casualty Test}

Granger Casualty test has been used to test for the causes and effect relationship between the Future market prices and the spot market prices. This test would help us know about the Lead-lag relationship between the future and spot market i.e. future market prices lead the spot market prices or the spot market prices lead the future market prices.

The empirical results of table 4.5 showed the Engle-Granger Casualty test results.

The results suggested that future market prices Granger causes the spot market prices based on the F-value 7.071 and its P-value 0.0003 which is greater than the critical value and thus Null hypothesis is rejected while the alternate hypothesis is accepted and thus future prices Granger Causes the spot prices. However for the spot prices causes the future hypothesis has not been supported for the reason of having less f-value 1.885 than the critical value while higher probability value O.152.Therefore it can be concluded that spot Index does not Granger Cause Future index. Now based on the above results, it can be concluded that the future market leads to the spot market.

Table 3.5 Pairwise Granger Causality Tests

\begin{tabular}{|l|l|l|}
\hline Null Hypothesis & F-statistics & Probability \\
\hline Spot Index does not Granger Cause Future index & 1.885 & 0.152 \\
Future Index does not Granger Cause Spot index & 7.971 & $0.0003^{* * *}$ \\
\hline
\end{tabular}

Table 3.5 shows the results of Engle Granger Casualty Test. *** shows level of significance at $1 \%$ confidence intervals.

\section{Conclusion and Future Research Directions}

This study was conducted to investigate the lead-lag relationship between the future market prices and spot market prices. For the empirical analysis, daily stock prices and future prices have been collected from the Karachi stock exchange website for the period of January 2005 to March 2012 for randomly selected forty firms. GARCH $(1,1)$ model has used to investigated the volatility in the spot and future prices. The empirical analysis concluded that historical volatility in the market prices has an impact on the current market price volatility in both of the spot as well as the future prices. Moreover the results further suggested that the future market price volatility has more prominent and persistent value to explain the spot market prices as compared to the explanatory power of the future market prices based on the spot market prices. So based on the GARCH $(1,1)$ model, the future market leads the spot market. The news shock arrives at the future market and then it transfers to the spot market prices. That is why the volatility of the future market prices can better explain the spot prices.

In order to triangulate the results of the GARCH $(1,1)$ model another test has used called Engle Granger Casualty test to investigated the Lead-Lag relationship between the future market prices and spot market prices. The results of the casualty test supported the $\operatorname{GARCH}(1,1)$ results and the future market prices Granger causes the spot market while the spot market does not Granger causes the future market. It can be concluded based on these analyses that it's the future market 
prices that lead the spot market prices and thus there exists a Lead-Lag relationship between the future and spot prices of the Karachi stock exchange and one can predict changes spot market prices based on the changes in the future market prices.

This research was done to investigate the Lead-lag relationship based on the prices of spot and future market. In order to make more insight in this relationship one can include the trading volume as well as while explaining volatility in either of spot and future market prices. Other factors such as value added tax, capital gain tax, law and order situation and sentiments of the investors play important role in the lead-lag relationship between the spot and future market prices. 䛧

\section{References}

Abhyankar, A. H. (1995), 'Return and volatility dynamic in the FT-SE 100 stock index and stock index futures markets', Journal of Futures Market, Vol. 15(4), pp. 457-488.

Abhyankar, A. (1998), 'Linear and Nonlinear Granger Causality: Evidence from the U.K. Stock Index Futures Market', The Journal of Futures Markets, 18 (5), pp. 519-540.

Alexakis, P. M. Kavussanos, and I. Visvikis (2002), 'An Investigation of the Lead-Lag Relationship in Returns and Volatility between Spot and Stock Index Futures: The Case of Greece', European Financial Management Association, Annual meeting 2002.

Antoniou, A. and P. Holmes (1995), 'Futures trading, information and spot price volatility: Evidence for the FTSE-100 stock index futures contract using GARCH', Journal of Banking and Finance, Vol. 19, pp.117-129.

Antoniou, A. G. Pescetto, and A. Violaris (2003), 'Modelling International Price Relations and Interdependencies Between the Stock Index and Stock Index Futures Markets of Three EU Countries: A Multivariate Analysis', Journal Of Business Finance \& Accounting, 30 (5) \& (6).

Athianos, S. (2002), 'The four problems of Greek derivative market', Newspaper Isotimia, March 2002, 14/54.

Athianos, S. and Lake. A (2004), 'Simultaneity and causality between FTSE/ASE 20 future index, FTSE/ASE 20 spot market index and the respective volatilities in Greece', 16 Statistical Conference, Kavala.

Bessimbinder, H. and P.J. Seguin (1992), 'Futures trading activity and stock price volatility', Journal of Finance. Vol. 47, pp. 2015-2034.

Bollerslev, T. (1986), 'Generalized Autoregressive Conditional Heteroskedasticity', Journal of Econometrics, Vol. 31, pp. 307-327

Bologna, P. and L. Cavallo (2002), 'Does the introduction of stock index futures 
effectively reduce stock market volatility? Is the futures effect immediate? Evidence from the Italian stock exchange using GARCH', Applied Financial Economics, Vol.12, pp. 183-192.

Booth, G.G. W.S. Raymond, and Y. Tse (1999), 'Price discovery in the German equity derivatives markets', The Journal of Futures Markets, Vol. 19(6), pp. 619-643.

Blume, M.E., A.C. MacKinlay, and B. Terker (1989), 'Order imbalances and stock price movements on October 19 and 20, 1987’, Journal of Finance, Vol. 44, pp.827-848.

Brooks, C. I. Garrett, and M. J. Hinich (1999), 'An Alternative Approach to Investigating LeadLag Relationships between Stock and Stock Index Futures Markets', Applied Financial Economics, Vol. 9, pp. 605-613.

Chan, K. and P.Y. Chung (1993), 'Intraday relationships among index arbitrage, spot and futures price volatility, and spot market volume: A transaction data test', Journal of Banking and Finance, Vol. 17, pp. 663-687.

Chan, K. (1992), 'A further analysis of the lead lag relationship between the spot market and stock index futures market' Review of Financial Studies, Vol. 5, pp. 123-152.

Chan, K. K. C. Chan, and Karolyi (1991), 'Intraday volatility in the stock index and stock index futures market', Review of Financial Studies, Vol. 4, pp.657-684.

Chatrath, A. S. Ramchander, and F. Song (1996), 'The role of futures trading activity in exchange rate volatility', Journal of Futures Markets, Vol. 16, pp. 561-584.

Cheung, Y. W. and H. G. Fung (1997), 'Information Flows between Eurodollar Spot and Futures Markets', Multinational Finance Journal, Vol. 1 (4), pp.255-271.

Damodaran, A. (1990), 'Index futures and stock market volatility', Review of Futures Markets, Vol. 9, pp. 442-457.

Darrat, A. and S. Rachman (1995), 'Has futures trading activity caused stock price volatility?', Journal of Futures Markets ‘, Vol.15, pp. 537-557.

De Jong, F. and T. Nijman (1997), 'High frequency analysis of lead-lag relationships between financial markets', Journal of Empirical Finance, Vol.4, pp.259-277.

Engle, R. F. (1982), 'Autoregressive Conditional Heteroskedasticity with Estimates of the Variance of the United Kingdom Inflation', Econometrica, Vol. 50 (4), pp.987-1007.

Floros, C. and D.V. Vougas (2008), 'Lead lag Relationship between Futures and Spot Markets in Greece 1999 - 2001', International Research Journal of Finance and Economics, Issue 7.

Granger, C.W.I. (1969), 'Investigating Causal Relations by Econometric Models and CrossSpectral Methods', Econometrica, Vol. 37, pp.423-438 
Green, J.C. and E. Joujon (2000), 'Unified tests of causality and cost of carry: the pricing of the French stock index futures contract', International Journal of Finance And Economics, Vol.5, pp. 121-140.

Harris, L. (1989), ‘S\&P 500 spot stock price volatilities’, Journal of Finance, Vol. 144(5), pp. 1155-1175.

Hogan, K.C., K.F. Kroner, and J. Sultan (1997), 'Program trading, nonprogram trading, and market volatility', Journal of Futures Markets, Vol. 17, pp.733-756.

Kawaller, I. G. P. D. Koch, and T. W. Koch (1987), 'The temporal price relationship between S\&P 500 futures and the S\&P 500 Index', Journal of Finance, Vol. 51(5), pp. 1309-1329.

Koch, P.D. (1993), 'Re-examining intraday simultaneity in stock index futures markets', Journal of Banking and finance, Vol. 17, pp.1191-1205.

Papachristou, G. (1999), 'Stochastic behavior of the Athens Stock Exchange: a case of institutional nonsynchronous trading', Applied Financial Economics, Vol. 9, pp. 239-250.

Pericli, A. and G. Koutmos (1997), 'Index futures and options and stock market volatility’, Journal of Futures Markets, Vol.17, pp.957-974.

Silvapulle, P. and I. A. Moosa (1999), 'The Relationship between Spot and Futures Prices: Evidence from the Crude Oil Market', The Journal of Futures Markets, Vol.19 (2), pp. 175-193.

Sofianos, G. (1993), 'Index Arbitrage Profitability', Journal of Derivatives, Vol.1(1), pp. 7-20.

Stoll, H. R. and R. E. Whaley (1990), 'The dynamic of stock index and stock index futures returns', Journal of Futures Market, Vol. 25(4), pp.441-468.

Subrahmanyam, A. (1991), 'A theory of trading in stock index futures', The Review of Financial Studies, Vol. 4(1), pp.17-51.

Tse, Y., K., Chan, W., S., (2010.) The Lead-Lag relation between the SandP500 spot and futures markets: an intraday data analysis using threshold regression model, The Journal of Japanese economic Association, Vol. 61, No. 1

Zeckhauser, R. V. Niederhoffer (1983), 'The performance of market index futures contracts', Financial Analysts Journal, January-February 1983.

Zhang et al (2010): "Market Efficiency Test in the VIX Futures Market", CAMA Working paper No. 8/2010, The Australian National University, pp.1-29 
https://ir.iba.edu.pk/businessreview/vol8/iss1/10

DOI: https://doi.org/10.54784/1990-6587.1221

Business Review - Volume 8 Number 1

January - June 2013

A1. Graph showing Residuals plot

\section{Annexure}

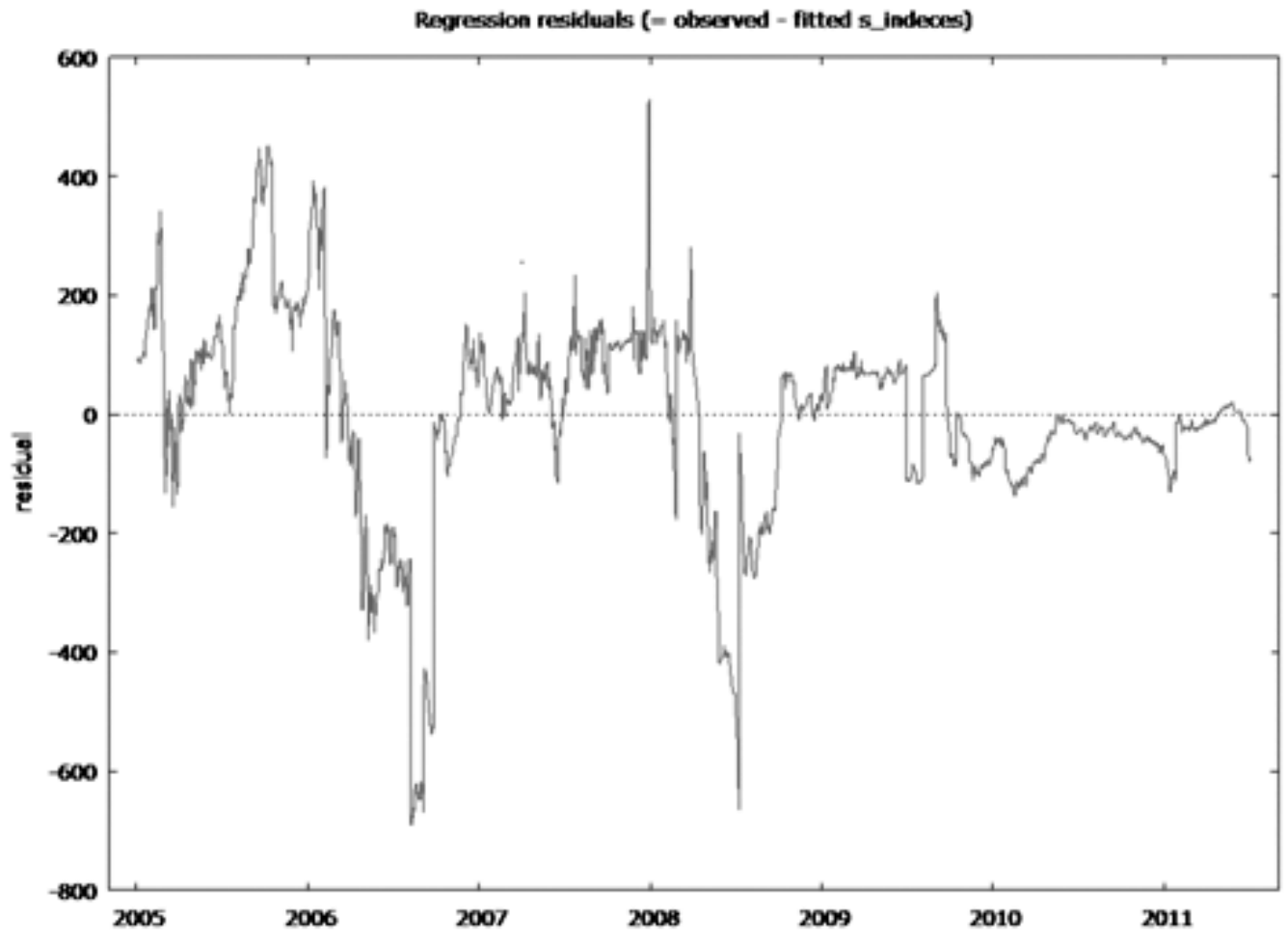

The above annexure shows the residual plot of the regression of spot prices over the future prices.

"There is no prescription for leadership. By definition, it is

individual. It is about morality, character and values. That's

why it is really an incredibly difficult task to take on."

M. S. 'Vindi' Banga 